
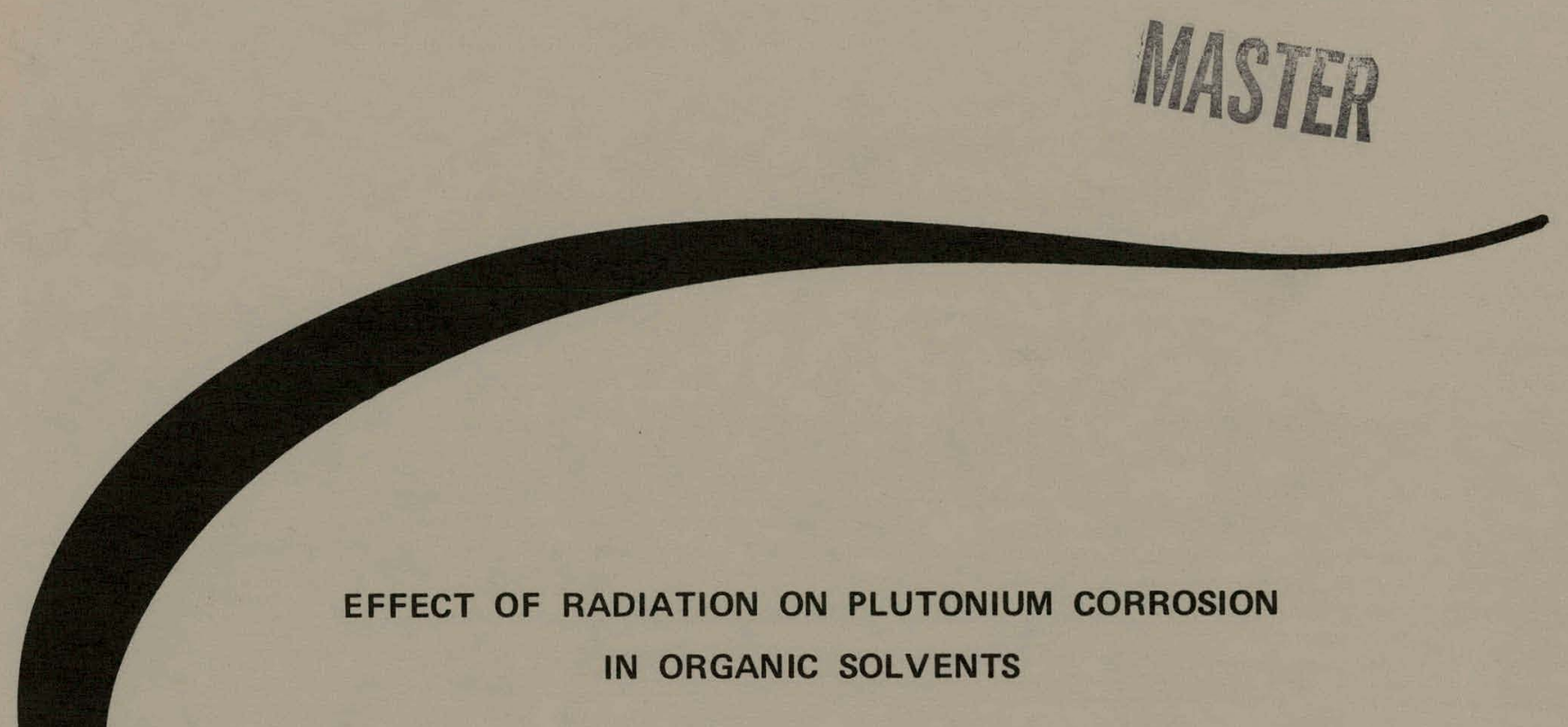

Armen R. Kazanjian

David R. Horrell

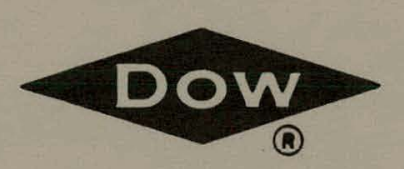

DOW CHEMICAL U.S.A. ROCKY FLATS DIVISION

P. O. BOX 888

GOLDEN, COLORADO 80401

U. S. ATOMIC ENERGY COMMISSION CONTRACT AT(29-1)-1106 


\section{DISCLAIMER}

This report was prepared as an account of work sponsored by an agency of the United States Government. Neither the United States Government nor any agency Thereof, nor any of their employees, makes any warranty, express or implied, or assumes any legal liability or responsibility for the accuracy, completeness, or usefulness of any information, apparatus, product, or process disclosed, or represents that its use would not infringe privately owned rights. Reference herein to any specific commercial product, process, or service by trade name, trademark, manufacturer, or otherwise does not necessarily constitute or imply its endorsement, recommendation, or favoring by the United States Government or any agency thereof. The views and opinions of authors expressed herein do not necessarily state or reflect those of the United States Government or any agency thereof. 


\section{DISCLAIMER}

Portions of this document may be illegible in electronic image products. Images are produced from the best available original document. 


\section{LEGAL NOTICE}

This report was prepared as an account of work spnnsored by the United States Government. Neither the United States nor the Unitcd States Atomic Energy Commission, nor any of their employees, nor any of their contractors, subcontractors, or their employees, makes any warranty, expressed or implied, or assumes any legal liability or responsibility for the accuracy, completeness or usefulness of any information, apparatus, product or process disclosed, or represents that its use would not infringe privately owned rights.

Printed in the United States of America

Available from the

National Technical Information Service

U. S. Deparlmenl of Commerce

Springfield, Virginia 22151

Price: Printed Copy $\$ 3.00$; Microfiche $\$ 0.95$ 


\title{
EFFECT OF RADIATION ON PLUTONIUM CORROSION \\ IN ORGANIC SOLVENTS
}

\author{
Armen R. Kazanjian
}

David R. Horrell

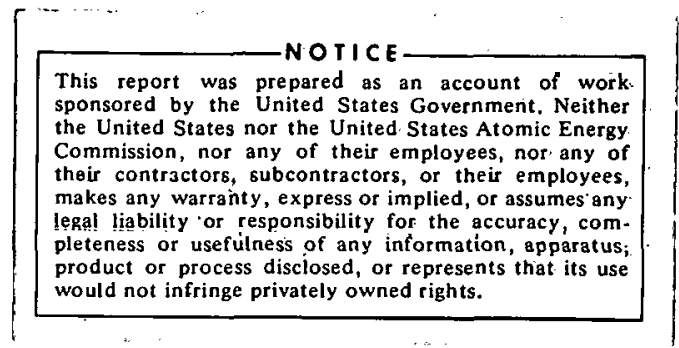

DOW CHEMICAL U.S.A

ROCKY FLATS UIVISIÓN

P. O. BOX 888

GOLDEN, COLORADO 80401

Prepared under Contract AT(29-1)-1106

$$
\text { for the }
$$

Albuquerquc Opcrotions Officc

U. S. Atomic Energy Commission 


\section{CONTENTS}

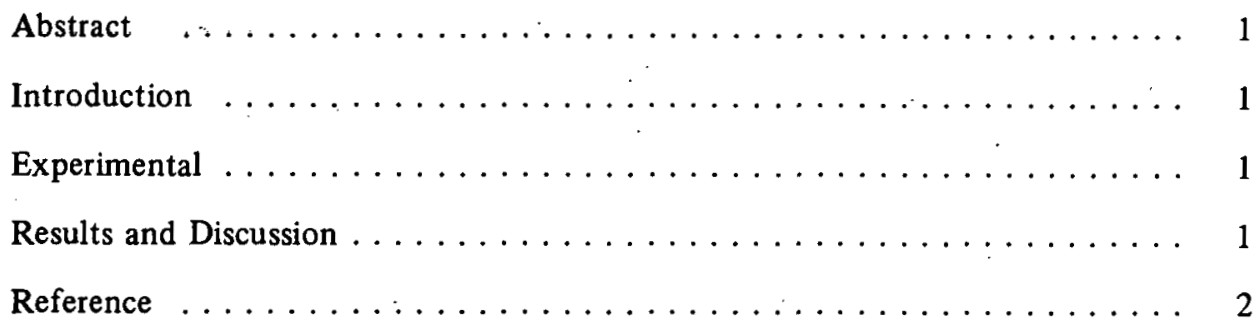




\title{
EFFECT OF RADIATION ON PLUTONIUM CORROSION IN ORGANIC SOLVENTS
}

\author{
Armen R. Kazanjian and David R. Horrell
}

\begin{abstract}
Corrosion tests were made on plutonium metal in contact with carbon tetrachloride, trichloroethylene, chloroform, perchloroethylene, 1, 1, 2-trichlorotrifluoroethane, hexane, and Texaco Regal A oil. These tests were made under irradiation and nonirradiation conditions to determine whether radiation would enhance the corrosion rate. Enhancement did occur in chloroform and in hexane. The major radiation products, hydrogen chloride in chloroform and hydrogen in hexane, are able to readily react with plutonium.
\end{abstract}

\section{INTRODUCTION}

During fabrication, plutonium comes into contact with organic solvents and lubricants. These liquids are chemically inert, relatively, and would not be expected to corrode the metal. However, the alpha radiation from plutonium would slowly alter these compounds so that corrosion would be more likely over a long period. This investigation was made to determine whether radiation enhances the corrosion of plutonium by carbon tetrachloride, trichloroethylene, chloroform, perchloroethylene, $1,1,2$. trichlorotrifluoroethane, hexane, and Texaco Regal A oil. This was done by gamma irradiation of plutonium coupons immersed in these liquids, and comparing the corrosion with those of nonirradiated specimens. The gamma doses administered were much greater than the alpha doses emanating from the plutonium.

\section{EXPERIMENTAL}

The plutonium used was in the delta phase (1 wt\% gallium stabilized) and in the form of disks $(7 / 8$-in. diameter and $1 / 8$-in. thick). The corrosivity of the following liquids was examined.

Carbon tetrachloride, $\mathrm{CCl}_{4}$ - Baker Analyzed Reagen.t

Trichlorethylene, $\mathrm{C}_{2} \mathrm{HCl}_{3}$ - Baker Analyzed Reagent

Chloroform, $\mathrm{CHCl}_{3}-\mathrm{B} \& \mathrm{~A}$ Analyzed Reagent

Perchlorethylene, $\mathrm{C}_{2} \mathrm{Cl}_{4}-$ Dow Unstabilized Solvent

1, 1, 2-Trichlorotrifluoroethane, $\mathrm{C}_{2} \mathrm{Cl}_{3} \mathrm{~F}_{3}$ - Genesolv-D (99.999\%, Allied Chemicial Corporation)

Hexane, $\mathrm{C}_{6} \mathrm{H}_{14}$ - Baker Analyzed Reagent

Texaco Regal A Oil - Light hydraulic oil

Before a corrosion test the plutonium coupons were cleaned with a wire brush and after the immersion period with a Nylon brush. Carbon tetrachloride was used for rinsing. The coupons, resting on glass holders, were immersed in $70 \mathrm{ml}$ of liquid contained in glass beakers which were covered and taped to exclude water vapor. The liquids were maintained at room temperature $\left(25^{\circ} \mathrm{C}\right)$, with and without irradiation, and were not stirred.

The radiation source was Cobalt -60 with a gamma dose rate of $1.2 \times 10^{18} \mathrm{eV} / \mathrm{ml}$ minute as determined by ceric sulfate dosimetry. The plutunium-liquid system was irradiated for 24 hours, then allowed to remain in contact for 4 more days. In the nonirradiation tests, the plutonium coupons were immersed for 5 days. The extent of corrosion was determined by weight change and visual inspection.

\section{RESULTS AND DISCUSSION}

The corrosion tests were all made in duplicate and the results, expressed as milligrams per day per square decimeter (mdd), are presented in Table 1. The plus and minus signs refer to weight gain and loss, respectively.

Table 1. Corrosion Rates (in mdd).

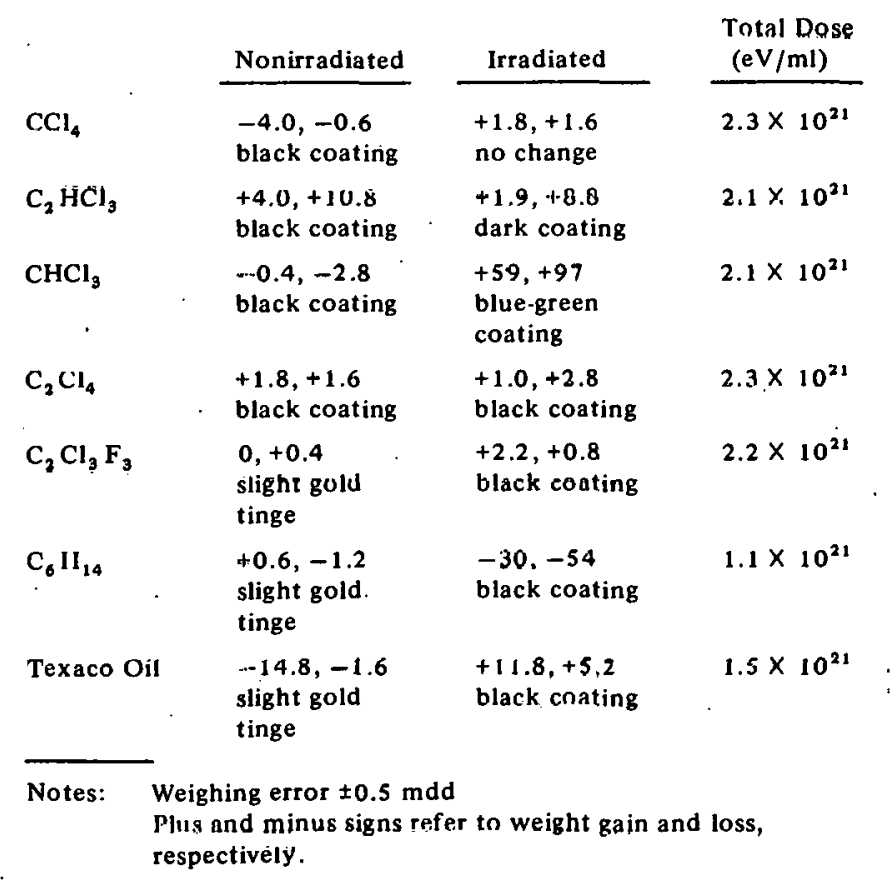


-With the exception of plutonium in irradiated chloroform and hexane, the corrosion rates are considered to be almost negligible. Rates less than 10 mdd are very low and the cleaning procedure would probably add a sizeable error to these small values. This error could only be determined by running many additional samples on each system, but this was not done. Air was not excluded from the samples and could be responsible for a small amount of corrosion. It is therefore concluded that these liquids are essentially inert toward plutonium and in most cases the reactivity is not enhanced by radiation doses up to $2.3 \times 10^{21} \mathrm{eV} / \mathrm{ml}$.

Irradiated $\mathrm{CHCl}_{3}$ has previously been shown to be very corrosive toward metals. ${ }^{1}$ The corrosion is probably caused by dissolution by $\mathrm{HCl}$, which radiation produces in $\mathrm{CHCl}_{3}$ in a high yield. The small amount of water in $\mathrm{CHCl}_{3}$ most likely facilitates the dissolution because dry $\mathrm{HCl}$ is not reactive toward plutonium. The corrosion product, which is probably plutonium chloride, is fairly adhesive and the mdd values are weight gains rather than weight losses as is the case in irradiated hexane. The corrosion product in hexane is assumed to be the hydride, which can easily be rubbed off. Hydrogen, the major radiation product in hexane, readily reacts with plutonium to form the hydride. Hydriding would also be expected to occur in Texaco oil but does not. Texaco oil is predominantly a mixture of saturated hydrocarbons and its major radiation product is hydrogen. The hydrogen produced could be reactive with other components in the oil; for example, the unsaturated compounds or the corrosion inhibitor that is present in the oil.

The radiation corrosion rates, particularly for $\mathrm{CHCl}_{3}$ and $\mathrm{C}_{6} \mathrm{H}_{14}$, apply only to the given gamma dose and the experimental conditions. Increased doses would, of course, increase the corrosion rate. In thcsc tcsts the total dose given to the $70 \mathrm{ml}$ of liquid was $1.4 \times 10^{23} \mathrm{eV}$. This is to be compared to the total alpha dose of $1.2 \times 10^{20} \mathrm{eV}$ from the plutonium coupon.

\section{REFERENCE}

1. A. R. Kazanjian and D. R. Horrell, "Radiation Induced Corrosion of Metals," USAEC RFP-1881, Rocky Flats Division, Dow Chemical U.S.A., September 1972. 